\title{
GULA DARAH DAN BERAT BADAN TIKUS PUTIH SPRAQUE DAWLEY DIABETES MELITUS SETELAH TERAPI FRAKSI ETIL ASETAT MINUMAN SCJM
}

\author{
[Blood Sugar Body Weight White Spraque Dawley Diabetes Melitus Rats After Treatment The Ethyl \\ Asetat Fraction Scjm Drink]
}

\section{N. K. Wiradnyani}

Program S1 Ilmu Gizi, Universitas Dhyana Pura Email: wiradnyani@undhirabali.ac.id

Diterima 27 Juli 2019 / Disetujui 06 November 2019

\begin{abstract}
Sinom drinks mixed with lime and honey are made from rhizome of turmeric and young tamarind leaves which are added with lime juice and honey. The aim of the study was to determine the dose of ethyl acetate fraction of sinom drinks mixed with lime juice and honey (SCJM) which lowers fasting blood sugar and has an effect on body weight of spraque dawley (SD) white rats diabetes mellitus. Experimental research using RAK, testing consisted of two phases. Fiirst phase was antioxidant capacity test of various solvents of SCJM yielding $29691.1 \mu \mathrm{g}$ AAEAC / $\mathrm{g}$ ingredients namely the highest number of ethyl acetate fractions of $n$ - hexane, chloroform, and water. Second phase was in vivo test of ethyl acetate fraction of SCJM which can reduce the best GDP and weight to $S D$ white rats with diabetes mellitus with various doses, namely: control (-) normal mice, 50, 100, 150, $200 \mathrm{mg} / \mathrm{dl} B W$, control (+) of diabetic rats. The data was statistically tested using ANOVA with further test BNT. The results of the study of the effect of the antioxidant compound SCJM ethyl acetate fraction of various doses significantly affected $(p<0.01)$ in decreasing fasting blood sugar (GDP) white $S D$ diabetes mellitus rats, a dose that can reduce the lowest GDP based on statistical tests is $150 \mathrm{mg} / \mathrm{kg} \mathrm{BW}$ of rats, 168.4 $\mathrm{mg} / \mathrm{dl}$ from other doses. Rats body weight had no significant $(p<0.01)$ effect after treatment of the SCJM etyl acetate fraction.
\end{abstract}

Keywords: antioxidant capacity, blood sugar, ethylacetate_ fraction, sinom mix of lime and honey

\section{ABSTRAK}

Minuman sinom yang dicampur jeruk nipis dan madu terbuat dari rimpang kunyit dan daun asam muda yang ditambahkan air jeruk nipis dan madu. Tujuan penelitian adalah untuk menentukan dosis fraksi etil asetat minuman sinom campuran jeruk nipis dan madu (SCJM) yang menurunkan gula darah puasa (GDP) dan menimbulkan efek terhadap berat badan tikus putih spraque dawley (SD) diabetes melitus. Penelitian eksperimental menggunakan RAK terdiri dari dua tahap. Tahap pertama adalah uji kapasitas antioksidan berbagai pelarut (SCJM) menghasilkan $29691,1 \mu \mathrm{g}$ AAEAC/g bahan yaitu angka tertinggi fraksi etil asetat dari $n-$ heksana, khloroform dan air. Tahap ke-2 adalah uji in vivo fraksi etil asetat SCJM yang dapat menurunkan GDP terbaik dan berat badan tikus putih SD diabetes melitus dengan perlakuan berbagai dosis yaitu: kontrol (-) tikus normal 50, 100, 150, 200 mg/dl BB, kontrol (+) tikus diabetes. Data diuji statistik menggunakan Anova dengan uji lanjut BNT. Hasil penelitian senyawa antioksidan SCJM fraksi etil asetat berbagai dosis berpengaruh nyata $(p<0,01)$ pada penurunan GDP tikus putih SD diabetes melitus, dosis terbaik yang dapat menurunkan GDP terendah berdasarkan uji statistik adalah $150 \mathrm{mg} / \mathrm{kg}$ BB tikus yiatu 168,4 mg/dl dari perlakuan dosis yang lain. Berat badan tikus tidak berpengaruh nyata $(p<0,01)$ setelah pemberian fraksi etil asetat SCJM.

Kata Kunci : fraksi etilasetat, gula darah, kapasitas antioksidan, sinom campuran jeruk nipis dan madu

\section{PENDAHULUAN}

Kapasitas antioksidan minuman sinom (MS) pada fraksi air yaitu 199,100 $\mu \mathrm{g}$ AAEAC (Ascorbic Acid Equivalent Antioksidan Capacity) /g bahan diketahui memiliki kapasitas antioksidan yang paling tinggi diantara fraksi n-heksana (42,800 $\mu \mathrm{g} \mathrm{AAEAC/g}$ bahan), kloroform $(94,200 \mu \mathrm{g}$ AAEAC/g bahan), etil asetat $(66,600 \mu \mathrm{g}$ AAEAC/g bahan) (Wiradnyani, 2018) dan teruji dengan metode GCMS, diduga mengandung senyawa tumeron (49,84\%), artumeron (21,32\%), curlon $(27,25 \%)$ dan 9-oktadekanoat $(69,43 \%)$ (Wiradnyani, 2014). Fraksi etil asetat, khloroform dan $n$ - heksana mengandung senyawa yang diduga seperti tumeron, artumeron dan curlon memiliki prosentase relative lebih kecil dari fraksi air (Wiradnyani, 2014). Minuman sinom adalah 
minuman yang diolah dengan bahan utama rimpang kunyit dan daun asam yang masih muda, diambil dari pucuk daun sampai helai ke-tujuh. Menurut Norton (2008) secara alamiah kunyit dipercaya memiliki kandungan fitokimia yang dapat berfungsi sebagai analgetika, antipiretika, dan antiinflamasi, begitu juga daun asam muda (asam jawa) kaya akan flavonoid, fenol dan saponin sedangkan daun berfungsi sebagai antioksidan, antiinflamasi, antipiretika, dan penenang. Penambahan air jeruk nipis dan madu memberikan aroma yang lebih segar dan harum, dapat juga mengurangi rasa pahit dari rasa kunyit, menambah nutrisi secara alami, selain dapat menghilangkan jerawat (Mumpuni, 2010). SCJM memiliki aktivitas biologis sebagai antikanker dan antioksidan (Wiradnyani, 2018). Kendatipun minuman sinom sudah banyak dirasakan oleh sebagaian besar masyarakat untuk menyembuhkan berbagai penyakit degenerative khususnya penyakit diabetes melitus dan dishmoria. dalam penggunaanya biasanya ditambahkan air jeruk nipis dan madu. Namun perlu dilakukan uji secara in vivo pada tikus putih SD diabetes melitus. Penentuan kapasitas antioksidan minuman sinom campuran jeruk nipis dan madu SCJM fraksi etil asetat secara kuantitatif pada penelitian ini bertujuan untuk mendapatkan dosis yang dapat menurunkan gula darah puasa terendah.

\section{Bahan}

\section{BAHAN DAN METODE}

Bahan utama yang digunakan dalam penelitian ini terdiri atas bahan baku dan bahan kimia. Bahan baku yaitu rimpang kunyit yang diperoleh dari pasar tradisional Badung, Denpasar, Bali, daun asam yang masih muda dari pucuk daun sampai helai daun ke-tujuh dari daerah Buduk, Mengwi, Badung, Bali, air jeruk nipis, dan madu hutan dari daerah Sumba. Bahan kimia yang digunakan terdiri atas pelarut etil asetat, khloroform, n-heksana (PA merek Emsure Acs 215), kertas saring (Whatman no.1), asam askorbat, $\mathrm{H}_{2} \mathrm{SO}_{4}$, DPPH, methanol, Nicotinic acid, B2 vitamin powder, acetone $\mathrm{NH}_{4} \mathrm{OH}$, Indikator, Silika gel
GF254 (Merck), 1gr Aloksan dosis 50 mg/dl BB tikus, 40 tikus putih SD dari Balai Veteriner Farmako Surabaya, aquades, air demineralisasi, formalin, asam sitrat, natrium sitrat, dan pakan tikus standar, buffer.

Alat

Peralatan yang digunakan adalah timbangan analitik, timbangan biasa, spektrofotometer Shimadzu UV-160, rotary vacum evaporator, aluminium foil, kain saring, eksikator, vortex, magnetic stirrer, blood glucose test meter (Nesco), botol gelap, glucose stick (Nesco), 8 buah kandang tikus $35 \times 35 \mathrm{~cm}$, jarum sonde $2 \mathrm{cc}$ dan peralatan gelas untuk analisis.

\section{Lokasi Penelitian}

Penelitian ini dilaksanakan di
Laboratorium Pengolahan Pangan dan
Laboratorium Analisis Pangan Fakultas
Teknologi Pertanian, Universitas Udayana,
Laboratorium Pusat Studi Pangan dan Gizi
Universitas Udayana, Laboratorium Kimia
Forensik Polri Bali, Laboratorium bersama
Universitas Dhyana Pura.

\section{Metode}

\section{Penelitian Tahap Ke-1}

Uji kapasitas antioksidan dilakukan dengan cara: penyiapan sampel rimpang kunyit yang diperoleh di pasar tradisional Badung, Denpasar, Bali dan daun asam yang masih muda dari pucuk daun sampai helai ketujuh dari daerah Jimbaran, kabupaten Badung, Provinsi Bali. Rimpang kunyit dikupas, ditimbang sebanyak 50 gram, dicuci, dihaluskan menggunakan blender dengan menambahkan $400 \mathrm{ml}$ air selama 3,5 menit, disaring untuk mendapatkan filtrat, kemudian dipanaskan sampai mendidih selama 1 menit. Filtrat yang diperoleh lalu dicampur dengan filtrat daun asam muda yang sudah dicuci, diperoleh dengan cara menimbang seberat 250 gram daun asam muda, ditambahkan 300 $\mathrm{ml}$ air, kemudian dipanaskan dengan cara mendidihkan selama 1 menit. Setelah dingin setiap $100 \mathrm{ml}$ ditambahkan 10 gram air jeruk nipis dan madu. Minuman SCJM selanjutnya dimasukan ke dalam botol kaca dan 
didinginkan sampai tidak ada uap panasnya, selanjutnya siap digunakan untuk pengujian.

Fraksinasi minuman SCJM dengan menggunakan etil asetat, yang dilakukan sebagai berikut: $100 \mathrm{ml}$ minuman SCJM dimasukan ke dalam labu pisah yang telah dikeringkan dalam oven selama 15 menit pada suhu $100^{\circ} \mathrm{C}$, selanjutnya ditambahkan etil asetat $100 \mathrm{ml}$, dikocok 10 kali dan didiamkan selama 30 menit. Fraksi etil asetat dievaporasi dengan suhu $45^{\circ} \mathrm{C}$ dan tekanan 280 mbar untuk menghilangkan pelarut. Uji antioksidan fraksi minuman SCJM dilakukan berdasarkan penelitian (Winarsi, 2007) dengan rumus:

$\underline{\text { Konsentrasi }(\mathrm{ppm}) \times \mathrm{TV} \times \mathrm{Fp} \times 1000.000}$ W sampel $(\mathrm{mg})$

Keterangan: $\mathrm{Tv}=$ total volume (liter), $\mathrm{Fp}=$ faktor pengeceran, Konsentrasi $=$ hasil penghitungan kurva standar, AAEAC $=$ Ascorbic Acid Equivalent Antioksidan Capacity.

\section{Penelitian Tahap Ke-2}

Tahap penelitian eksperimental secara in vivo dengan menggunakan Rancangan Acak Kelompok

\section{Pengukuran Berat Badan Tikus}

Hewan coba yang digunakan adalah tikus Sprague Dawley (SD) jantan dewasa berumur dua bulan, dengan berat rata-rata $210 \mathrm{gr}$ - $250 \mathrm{gr}$ sebanyak 25 ekor, yang diperoleh dari Balai Veteriner Farmako Surabaya. Tikus tersebut dimasukkan dalam kandang individu dengan ukuran panjang 150 $\mathrm{cm} \times$ lebar $15 \mathrm{~cm} \times$ tinggi $15 \mathrm{~cm}$ yang telah dilengkapi tempat makan dan minum dan setiap kandang ditempati satu ekor tikus. Tikus kemudian dikelompokan menjadi 5 kelompok sesuai rancangan penelitian. Setiap kelompok terdiri dari 4 ekor sebagai ulangan sehingga total tikus adalah 20 ekor. Semua tikus ditempatkan dalam ruang yang bersih, suhu nyaman $\pm 23^{\circ} \mathrm{C}$, kondisi gelap terang secara alami. Sebelum tikus diberi perlakuan ada masa adaptasi selama 7 hari dengan diberi makan pakan standar dan minum secara ad libitum. Pemberian makan dilakukan pagi hari dari jam 7.00-8.00 WITA, sebanyak 20 gram, setiap hari ditimbang berat badannya.
Pembuatan tikus diabetes melitus mengikuti cara kerja (Andayani, 2003). Tikus dipelihara dalam kandang selama 7 hari untuk menyeragamkan cara hidup dan makanannya, makanan dan minuman diberikan secara ad libitum. Kesehatan tikus dipantau setiap hari, dan berat ditimbang setiap hari. Bila ada sakit akan diobati oleh dokter hewan. Setelah masa adaptasi selama 7 hari, selanjutnya dilakukan pengukuran kadar glukosa darah. Sebelum dilakukan pengukuran kadar glukosa darah, tikus dipuasakan terlebih dahulu selama 16 jam. Induksi dilakukan dengan menggunakan $5 \%$ larutan streptocotozin (STZ) dalam larutan asam sitrat dan natrium sitrat $0,9 \%$ dengan dosis $50 \mathrm{mg} / \mathrm{kg}$ BB secara intraperitonial (Andayani, 2003). Setelah hewan diinduksi, diberi makanan yang cukup (ad libitum) dan dalam waktu 24 jam pertama dalam air minumnya ditambahkan $5 \%$ larutan D-glukosa monohidrat untuk mencegah terjadinya hipoglikemia yang fatal. Pengukuran kadar glukosa darah dilakukan 3 hari setelah induksi. Tikus dikatakan DM jika kadar glukosa darah puasa $>126 \mathrm{mg} / \mathrm{dl}$ atau kadar gula sesaat > $135 \mathrm{mg} / \mathrm{dl}$, Glukosa darah tikus normal $109 \mathrm{mg} / \mathrm{dl}$. Pengukuran berat badan (BB) tikus dilakukan pada setiap pukul 07.00 wita sebelum makan dan pemberian sampel fraksi etil asetat SCJM. Pengukuran dilakukan sampai

\section{Penentuan Dosis}

Penetapan dosis dan persiapan fraksi minuman SCJM adalah: dosis yang diberikan adalah dosis lazim konsumsi suplemen per hari pada manusia yang dikonversi dari manusia ke tikus. Perhitungan pemberian dosis berdasarkan pada body surface area (BSA) mengikuti penelitian yang dilakukan oleh Reagan-Shaw et al (2007). Rumus konversi dosis disajikan sebagai berikut:

$\operatorname{HED}(\mathrm{mg} / \mathrm{kg})=$ animal dose $(\mathrm{mg} / \mathrm{kg}) X$ animal $\mathrm{Km} /$ huma $\mathrm{Km} \ldots \ldots . .(2)$

Diasumsikan suplemen antioksidan perhari pada manusia rata-rata sebesar 500 $\mathrm{mg} / 60 \mathrm{~kg} \mathrm{BB}$, maka HED (human equivalent dose) $(\mathrm{mg} / \mathrm{kg})=8,3$. Apabila dikonversi ke tikus maka perhitungan menjadi: 
$8,3 \mathrm{mg} / \mathrm{kg}=$ animal dose $(\mathrm{mg} / \mathrm{kg} \mathrm{BB}) \times 6 / 37$, animal dose $=8,3 \times 37 / 6,=51,2 \mathrm{mg} / \mathrm{kg} \mathrm{BB}$ (3)

Berdasarkan perhitungan di atas, maka dosis yang diberikan untuk tikus bervariasi dari 50, 100, 150 dan $200 \mathrm{mg} / \mathrm{kg}$ BB tikus. Fraksi etil asetat minuman SCJM sudah ditimbang beratnya sesuai dengan dosis yang akan diberikan pada tikus dilarutkan di dalam $2 \mathrm{ml}$ aquades, kemudian dihomogenkan dengan vortek agar tercampur dengan merata. Pemberian fraksi etil asetat SCJM cara ini bertujuan untuk mempermudah pemberian pada tikus putih secara oral yang diberikan sesuai dengan masing-masing dosis fraksi setiap pagi pada jam $07.30-08.00$ WIB.

Penelitin yang dilakukan secara bioassay menggunakan 20 ekor tikus putih SD dengan perlakuan dosis pemberian fraksi etil asetat minuman SCJM penelitian tahap ke-1 yang terdiri dari 5 taraf yaitu: tikus kontrol (-) diberikan fraksi etil asetat SCJM $0 \mathrm{mg} / \mathrm{kg}$ BB atau diberi aquades $2 \mathrm{ml} / \mathrm{ekor}$, tikus kontrol positif $(+)$ tikus diabetes tanpa pemberian $\mathrm{SCJM}$, diberikan secara oral (disonde) fraksi etil asetat SCJM: (K1) dosis $50 \mathrm{mg} / \mathrm{kg}$, (K2) dosis $100 \mathrm{mg} / \mathrm{kg}$, (K3) dosis $150 \mathrm{mg} / \mathrm{kg}$, (K4) dosis $200 \mathrm{mg} / \mathrm{kg}$ BB tikus, masing-masing ditambahkan $2 \mathrm{ml}$ aquades, pemberian satu kali sehari pagi hari. Masing-masing ada 5 kelompok dan 4 ekor tikus sebagai ulangan. Pengukuran kadar gula darah diadakan pada tahap ini, setiap 3 hari sekali dari pengambilan data ke-0, 3, 6, 9, 12, 15, 18 dan 21. Pemeriksaan gula darah dilakukan setiap jam 07.00-08.00 WITA, setelah dipuasakan selama 12 jam tetapi tetap diberi minum. Kadar gula darah diukur dengan alat blood glucose test meter Gluco Dr. Selanjutnya di analisis dengan menggunakan Annova $1 \%$, uji lanjut BNT.

Penentuan jumlah ulangan dan sampel: penelitian ini mengunakan 20 unit tikus jantan galur SD berumur dua bulan dengan berat badan 200 sampai dengan $250 \mathrm{gr}$, dari 20 ekor ini diambil masing-masing empat ekor untuk setiap taraf perlakuan sehingga jumlah ulangan adalah empat kali. Penggunaan jumlah sampel yang lebih besar pada penelitian ini untuk menghindari terjadinya kekurangan sampel sampai pada akhir penelitian yang diduga akibat kematian sampel.

\section{Analisis Data}

Uji kapasitas antioksidan fraksi etil asetat minuman sinom campuran jeruk nipis dan madu, berat badan tikus dan GDP dianalisis dengan menggunakan analisis varian (ANOVA). Apabila terdapat pengaruh yang bermakna (taraf $1 \%$ ) maka analisis dilanjutkan dengan uji beda rerata antar perlakuan dengan uji perbandingan berganda Uji Beda Nyata terkecil (BNT).

\section{HASIL DAN PEMBAHASAN}

Senyawa yang diduga terkandung dalam minuman SCJM setelah difraksinasi dengan menggunakan berbagai pelarut telah diketahui bahwa kapasitas antioksidan tertinggi adalah minuman SCJM yang menggunakan pelarut etil asetat. Minuman SCJM oleh GCMS terdeteksi 18 komponen senyawa penyusun (Wiradnyani, 2018). Hasil GCMS senyawa mayor ini memiliki aktivitas biologis sebagai antikanker dan antidiabetes (Wiradnyani, 2018)

Uji Kapasitas Antioksidan dimulai dengan penentuan standar asam askorbat atau vitamin $\mathrm{C}$ dalam mereduksi radikal bebas $\operatorname{DPPH}(1,1$-difenil-2-pikrilhidra-zi) $\quad 0,1 \quad \mathrm{mM}$ dapat dilihat pada Gambar 1 yaitu kurva kalibrasi asam askorbat standar hubungan kapasitas antioksidan ( $\mathrm{mg} / \mathrm{l}$ ) fraksinasi dengan pelarut etil asetat ekstrak minuman SCJM.

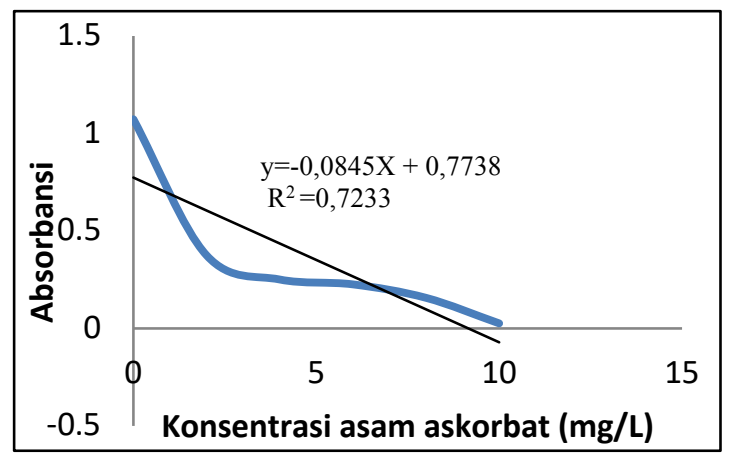

Gambar 1. Kurva Kalibrasi Asam Askorbat Standar

Hasil kapasitas antioksidan rata-rata minuman SCJM (Wiradnyani, 2018) 
Versi Online:

http://www.profood.unram.ac.id/index.php/profood e-ISSN: 2443-3446

Tabel 1. Hasil Pengujian Kapasitas Antioksidan ( $\mu \mathrm{g}$ AAEAC/g bahan) Perlakuan Berbagai Pelarut Minuman SCJM

\begin{tabular}{lc}
\hline \multicolumn{1}{c}{ Pelarut } & $\begin{array}{c}\text { Kapasitas Antioksidan } \\
(\boldsymbol{\mu g} \text { AAEAC } / \mathbf{g} \text { bahan })\end{array}$ \\
\hline n-Heksan & $16551.1^{\mathrm{ac}} \pm 4,688$ \\
Cloroform & $23819.1^{\mathrm{bc}} \pm 4,688$ \\
Etil Asetat & $29691.1^{\mathrm{d}} \pm 4,688$ \\
Air & $18089.7^{\mathrm{de}} \pm 4,688$ \\
\hline Notasi huruf yang berbeda dalam kolom yang sama \\
menunjukkan perbedaan yang signifikan pada \\
p<0,05 (BNT).
\end{tabular}

Kapasitas antioksidan minuman SCJM hasil fraksi dengan perlakuan berbagai jenis pelarut dari hasil penelitian dicantumkan pada Tabel 1. Besarnya kapasitas antioksidan fraksi etil asetat memiliki nilai tertinggi yaitu 2969,1 $\mu \mathrm{g}$ AAEAC/g bahan, dibandingkan $\mathrm{n}$ heksan (16551,1 $\mu \mathrm{g}$ AAEAC/g), kloroform $(23819,1 \mu \mathrm{g}$ AAEAC/g) dan air $(18089,7 \mu \mathrm{g}$ $\mathrm{AAEAC} / \mathrm{g})$.

Hal ini disebabkan oleh kemampuan senyawa bioaktif yang ada di dalam minuman SCJM sangat sesuai dengan sifat-sifat pelarut etil asetat sehingga sifat semi-polar pelarut etil asetat dimiliki juga oleh senyawa bioaktif minuman SCJM yang mampu mengkelat radikal bebas pada DPPH, penelitian ini sesuai dengan analisis senyawa antioksidan fraksi etil asetat daun Libo (Ficus Variegate Blume) yang di teliti oleh Novitasari (2016).

\section{Rata-Rata Gula Darah Puasa (GDP) dan Berat Badan Tikus Putih SD Diabetes Berbagai Dosis Fraksi Etil Asetat Minuman SCJM}

Pengujian GDP tikus SD diabetes dengan berbagai dosis fraksi etil asetat Minuman SCJM dapat dilihat pada Tabel 2.

Tabel 2. Rata-rata Gula Darah Puasa (GDP) $(\mathrm{mg} / \mathrm{dl})$ Berbagai Dosis Fraksi Etil Asetat Minuman SCJM (mg/kg) BB Tikus

\begin{tabular}{lcc}
\hline \multicolumn{1}{c}{$\begin{array}{c}\text { Perlakuan } \\
\text { (mg/Kg BB Tikus) }\end{array}$} & \multicolumn{2}{c}{$\begin{array}{c}\text { Nilai rata-rata GDP } \\
\text { Minuman SCJM } \\
\text { mg/dl }\end{array}$} \\
\hline kontrol - & $92.4 \mathrm{a} \pm$ & 16.57257 \\
dosis 150 & $109.8 \mathrm{a} \pm$ & 16.57257
\end{tabular}

dosis 100

dosis 50

dosis 200

kontrol +

$\begin{array}{rr}117.2 \mathrm{bc} \pm & 16.57257 \\ 168.4 \mathrm{~cd} \pm & 16.57257 \\ 232.8 \mathrm{e} \pm & 16.57257 \\ 337.4 \mathrm{f} \pm & 16.57257\end{array}$

$117.2 \mathrm{bc} \pm$

$232.8 \mathrm{e} \pm$

16.57257
Berdasarkan uji statistik, analisis keragaman menunjukkan bahwa senyawa antioksidan pada perlakuan berbagai dosis 50 , 100, 150, $200 \mathrm{mg} / \mathrm{kg}$ BB tikus, fraksi etil asetat minuman SCJM pada tikus SD diabetes melitus berpengaruh nyata $(p<0,01)$ terhadap GDP tikus.

Uji perbandingan berganda BNT menunjukkan bahwa pemberian dosis $0 \mathrm{mg} / \mathrm{kg}$ yaitu tikus kontrol (-) menunjukkan rata-rata GDP $(92,4 \mathrm{mg} / \mathrm{dl})$ Karena pemberian dosis 0 fraksi air minuman sinom yaitu katagori tikus sehat diduga dalam tubuh tikus secara alami dari reaksi biologis yang menghasilkan radikal bebas seperti ROS dan RNS sehingga secara alami pula tubuh memiliki pertahanan terhadap efek radikal bebas yang berasal dari vitamin C, oleh Veliky et al. (2001) Emiati (2007) Wiradnyani (2018) yang menyatakan bahwa aktivitas antiradikal dengan metode DPPH secara in vivo pada manusia didapatkan perlakuan kontrol atau tanpa konsumsi minuman kakao bebas lemak yang mengandung komponen fenolik ditemukan juga aktivitas antiradikal berkisar 17,5\%.

Dosis kontrol (-) yang berbeda nyata dengan pemberian dosis $50 \mathrm{mg} / \mathrm{kg}$ BB yaitu dengan rata-rata GDP $168,4 \mathrm{mg} / \mathrm{dl}$, maupun dengan pemberian dosis $100 \mathrm{mg} / \mathrm{kg}$ BB $(117,2$ $\mathrm{mg} / \mathrm{dl}$ ), hal ini diduga pada titik tertentu STZ sebagai diabetogenik, merupakan donor NO yang mampu meningkatkan ROS/Reactive nitrogen species (RSN). ROS menyebabkan kerusakan sel $\beta$, sebagai efeknya produksi insulin akan berkurang, oleh Badole, et al. (2007) dijelaskan bahwa akibatnya adalah diabetes tipe I. Hal ini diduga karena dosis 50 dan $100 \mathrm{mg} / \mathrm{kg}$ BB antioksidan fraksi etil asetat SCJM belum efektif untuk menurunkan GDP tikus diabetes (Wiradnyani, 2018). RNS dari STZ sangat toksik menyebabkan penurunan jumlah ATP, sintesis dan sekresi insulin terhambat yang menyebabkan hiperglikemia glukosa plasma menumpuk dalam aliran darah, karena kerusakan sel $\beta$ 
pankreas, sehingga insulin tidak dapat melakukan sintesis terhadap glikogen (terjadi peningkatan glukogenesis), sekresi insulin terganggu dalam kondisi glukosa plasma tinggi, sehingga kemampuan insulin secara normal menghambat keluarnya glukosa dari hati tidak terjadi lagi (Ganong, 2008).

Gambar 2 menjelaskan bahwa GDP tikus terbaik adalah yang diberikan dosis 150 $\mathrm{mg} / \mathrm{kg}$ karena memberikan nilai terendah $(168,4 \mathrm{mg} / \mathrm{dl})$, berbeda nyata dari perlakuan dosis yang lainya, Glutathione reduktase memperbaiki fungsi mitokondria sangat dibutuhkan untuk membuat flavin mononukleotida (FMN) dan flavin adenine dinukleotida (FAD). Antioksidan seperti ini lebih baik (sinergisme) kemampuannya mengkelat radikal bebas ada pada sel $\beta$ karena induksi Streptotozin (Setyo, 2012).

Dosis $200 \mathrm{mg} / \mathrm{kg}$ BB tikus kurang efektif diberikan pada tikus diabetes hal ini disebabkan antioksidan fraksi etil asetat yang berubah menjadi prooksidan sehingga kerja berbagai jenis antioksidan menjadi tidak spesifik dan kurang efektif dalam mengkelat radikal bebas (NO*) dari STZ pada dosis semakin tinggi. Roitt dan Delves (2001), Haliwell dan Gutteridge (1999) yang menyatakan bahwa kemungkinan pada saat melakukan apoptosis, semua isi sel $\beta$ akan keluar dan menghasilkan radikal bebas. Hal ini berakibat glukagon menstimulasi produksi badan keton dengan cara meningkatkan oksidasi asam lemak fraksi minuman sinom asam 9-octadecenoid acid dan menurunkan konsentrasi malonil CoA (Wiradnyani, 2018).

Uji perbandingan berganda BNT menunjukkan bahwa pemberian dosis $0 \mathrm{mg} / \mathrm{kg}$ yaitu tikus kontrol $(+)$ menunjukkan rata-rata GDP $(337,4 \mathrm{mg} / \mathrm{dl})$ yang berbeda nyata dengan pemberian dosis $50 \mathrm{mg} / \mathrm{kg}$ BB yaitu dengan rata-rata GDP $168,4 \mathrm{mg} / \mathrm{dl}, 100 \mathrm{mg} / \mathrm{kg}$ BB $(117,2 \mathrm{mg} / \mathrm{dl})$, maupun pemberian dosis $200 \mathrm{mg} / \mathrm{kg}$ BB $(232,8 \mathrm{mg} / \mathrm{dl})$ hal ini diduga sumbangan injeksi STZ sebagai diabetogenik. Dalam keadaan DM tikus mengalami defisiensi insulin dan glukagon yang berlebihan menghasilkan lingkungan hormonal yang mempermudah proses ketosis (Hardman, 2002).

Berdasarkan uji statistik, analisis keragaman menunjukkan bahwa senyawa antioksidan pada perlakuan berbagai dosis 50 , $100,150,200 \mathrm{mg} / \mathrm{kg}$ BB tikus, fraksi etil asetat minuman SCJM pada tikus SD diabetes melitus tidak berpengaruh nyata $(p<0,01)$ terhadap Berat Badan tikus hal ini sesuai dengan penelitian Kintoko et al. (2016) tentang efek binahong terhadap luka tikus, Wansyah et al. (2017) tentang potensi fraksi etil asetat daun torbangun dalam meningkatkan produksi susu. Grafik berat badan Tikus SD berbagai dosis fraksi etil asetat minuman SCJM disajikan pada Gambar 3.

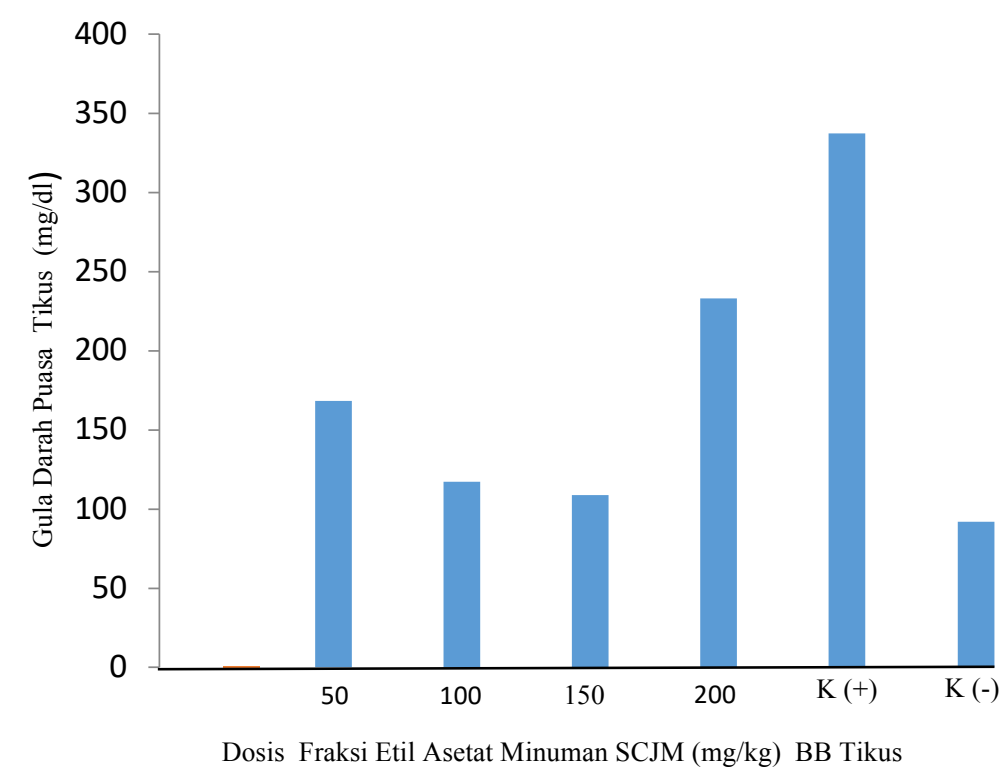

Gambar 2. Grafik Gula Darah Tikus Fraksi Etil Asetat SCJM 


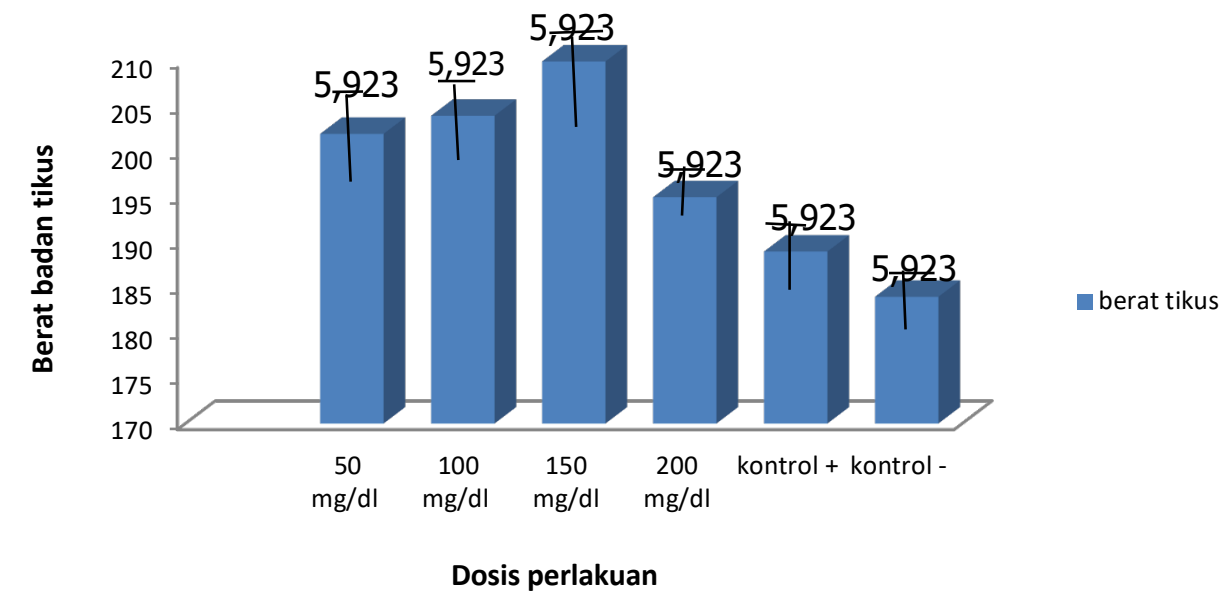

Gambar 3. Grafik Berat Badan Tikus SD Berbagai Dosis Fraksi Etil Asetat Minuman SCJM

\section{KESIMPULAN}

1. Perlakuan dosis fraksi minuman SCJM berpengaruh nyata $(p<0,01)$ terhadap GDP tikus putih SD diabetes melitus

2. Kapasitas antioksidan tertinggi SCJM berbagai pelarut adalah fraksi etil asetat (29691,1 ( $\mu \mathrm{g}$ AAEAC/g bahan)

3. Dosis terbaik yang dapat menurunkan GDP terendah berdasarkan uji lanjut BNT adalah $150 \mathrm{mg} / \mathrm{kg}$ BB dapat menurunkan GDP $168,4 \mathrm{mg} / \mathrm{dl}$.

4. Fraksi etil asetat minuman SCJM tidak berpengaruh nyata terhadap berat badan tikus putih SD diabetes.

\section{UCAPAN TERIMAKASIH}

Penulis mengucapkan terimakasih kepada Kemenristek Dikti yang telah mendanai penelitian ini.

\section{DAFTAR PUSTAKA}

Emiati. 2007. Efek Konsumsi Minuman Bubuk Kakao Bebas Lemak terhadap Sifat Antioksidan dan Proliferative Limfosit Manusia. Disertasi. Institut Pertanian Bogor. Bogor.

Ganong, W. F. 2008. Buku Ajar Fisiologi Kedokteran. Editors Edisi Bahasa Indonesia. Ed.22-Jakarta: EGC 347367

Mumpuni, Y.A., Wulandari. 2010. Cara Jitu Mengatasi Jerawat. Andi. Jogyakarta.
Norton, K.J. 2008. Menstruation DisorderCauses Symptom and Treatment of Dysmenorrhea. http://www-steady health.com/articles, menstruationdisorder-causes-symptom-andtreatments of Dysmenorrhea-a773 html.[diakses 3 Maret 2010].

Novitasari, M. R, L. Febrina, R. Agustina, A. Rahmadani, R. Rusli. 2016. Analisis GCMS Senyawa Aktif Antioksidan Fraksi etil asetat Daun Libo (Ficus variegate Blume), Jurnal Sains dan kesehatan 1(5):221-225.

Shaw- Reagan, S., M. Nihal, N. Ahmad. 2007. Dose Translation from Animal to Human Studies Revisited. Departement of Dermatology, Paul P. Carbone Comprehensive Cancer Center; Molecular and Environmental Toxicology Center, University of Wisconsin, Madison, Wisconsin, USA. The FASEB Journal article fj. 07-9574 LSF.

Setyo, P.D.H. 2012. Pengaruh Fraksi Etil Asetat Buah Labu Siam (Sechium edule (Jacq.) SW.) Terhadap Regenerasi Sel $\beta$ Pankreas pada Tikus Diabetes yang Diinduksi Aloksan. Sekolah Tinngi Ilmu Farmasi Yayasan Pharmasi Semarang. STIFAR. Semarang.

Wansyah, A. C., Damanah, M. R. M., Kustiadi, L. 2017. Potensi Fraksi Etil Asetat Daun Torbangun (Coleus amboinicus L.) dalam Meningkatkan Produksi Susu Bobot Badan Induk dan Anak Tikus. $J$ Gizi Pangan 12(1): 61-68. DOI: 1025182/J9p.2017.12.1.61-68 
Winarsi. 2007. Antioksidan Alami dan Radikal Bebas. Kanisius. Yogyakarta.

Wiradnyani, N.K., Wartini, N. M., Harsojuono, B.A., 2014. Komposisi Senyawa Antioksidan Minuman Sinom (Curcuma domestica Val - Tamarindus Indica L.), Scientific Journal of Food Technology 1(1): 10-23

Wiradnyani, N.K. 2018. Kapasitas Antioksidan Minuman Sinom. Proceeding Sintesa Undhira 1(6):381-389

Wiradnyani, N.K., Dhylla., H.D.P. 2018. Senyaw Penyusun Hasil Fraksi Etil Asetat Minuman Sinom Campuran Jeruk Nipis dan Madu (Curcuma domestica val- tamarindus indica l.). Media IImiah Teknologi Pangan 5(2): 73-79.

Wiradnyani, N.K. 2018. Dosage antioxidant drink sinom of $\beta$ cell langerhans islet white micespraque dawley diabetes mellitus. Materials Science and Engineering Journal. IOP Conf. Ser: Mater. Sci. Eng.434 012325. 